\title{
Islamic Banking and Finance
}

\author{
Diaa M. S. AlFarra
}

Submitted to the

Institute of Graduate Studies and Research in partial fulfillment of the requirements for the Degree of

\author{
Masters of Science \\ in \\ Banking and Finance
}

Eastern Mediterranean University

June, 2015

Gazimağusa, North Cyprus 
Approval of the Institute of Graduate Studies and Research

Prof. Dr. Serhan Çiftçioğlu Acting Director

I certify that this thesis satisfies the requirements as a thesis for the degree of Master of Science in Banking and Finance.

Assoc. Prof. Dr. Nesrin Özataç

Chair, Department of Banking and Finance

We certify that we have read this thesis and that in our opinion, it is fully adequate in scope and quality as a thesis for the degree of Master of Science in Banking and Finance.

Assoc. Prof. Dr. Eralp Bektaş

Supervisor

Examining Committee

1. Assoc. Prof. Dr. Eralp Bektaş

2. Assoc. Prof. Dr. Bilge Öney

3. Asst. Prof. Dr. Korhan Gökmenoğlu 


\begin{abstract}
Islamic Banking and Finance has been growing rapidly during the last decades. Descriptive analysis has been used in order to introduce the Islamic banking and finance and how it works. On other hand, clarify the Islamic Banking and Finance Systems and show how it works in part of liability and also profit and loss sharing basis. In addition to that, the main similarities and differences were properly identified, introduced and discussed in the paper. It is obvious that there are many similarities between both systems while the major differences lies on the accepted and charged interests in loans provided by conventional banks since Islamic banks do not accept interest as it is prohibited by Islamic law.
\end{abstract}

The paper also explained sufficiently the ability of Islamic banks to operate in Islamic and Non-Islamic populations' countries. Over the last years, Islamic banks gained the trust of clients in Islamic countries as well as there was a real demand for such systems in non-Islamic countries. Monetary policies under Islamic banking systems has been also introduced and explained. As well as, what are the tools and techniques that were used in order to ensure stability for banks?

Keywords: Islamic banking and Finance, Riba, Musharkah, Murabaha, Mudarabah, Islamic Monetary policy. 


\section{ÖZ}

İslami Bankacılık ve Finans son yıllarda hızla gelişmektedir. Bu tezde İslami bankacılığı tanıtmak ve nasıl yapıldığını anlatmak için betimsel analizler kullanılmıştır. Öte yandan, İslami Bankacılık ve Finans Sistemlerinin sorumlulukları dahilinde nasıl çalıştığını, kâr ve zarar ortaklığı esasına göre nasıl işlediğini göstermektedir. Buna ek olarak İslami bankacılık ile diğer klasik bankacılık sistemlerinin başlıca benzerlikleri ve farklılıkları uygun bir şekilde tanıtılmış ve tartışılmıştır. İki bankacılık sisteminin arasında çok benzerlik olduğu açıkça ortadadır. En büyük farklılık ise bilindik bankacılık sistemleri faiz karşılığında borç para vermeyi kabul ederken İslami bankacılığın İslam kurallarına göre de yasak olan bu faizi reddetmesidir.

Ayrıca tezde İslami bankacılığın müslüman ve müslüman olmayan ülkelerde kullanılabilirliğinden bahsedilmiştir. Son yıllarda İslami bankalar müşteriler tarafından güven kazandıkça müslüman olmayan ülkelerde de bu sisteme karşı ciddi bir talep ortaya çıkmıştır. Bunun yanında İslami bankalarda para politikasının açıklanmasının yanı sıra, bankanın istikrarını sağlamak amacıyla kullanılan araç gereç ve tekniklerden bahsediliyor.

Anahtar kelimeler: İslami bankacılık ve finans, Riba, Musharkah, Murabaha Mudarabah, İslami para politikası. 
To My Mother 


\section{ACKNOWLEDGEMNT}

First of all, I would like to very much thank almighty God for this success. I am grateful to many people including but is not limited to professors, family members and friends as well. A special word of gratitude to my supervisor Assoc. Prof. Dr. Eralp Bektaş for working closely with me on this thesis in spite of his busy schedule. His great ideas and important suggestions enhanced my thesis. I would like to include a special note of thanks to my family who supported me during the last two years. I am also grateful to my friends for sharing their truthful views, ideas and insights on a number of issues in relation to my thesis. I would like also to take this opportunity to express my gratitude to everyone who gave me his/her support throughout the course of my study. I am really thankful for their guidance and advice.

Finally but not least, I would like to extend my thanks to my parents, brothers and sisters. I would like also to give a special thanks to my mother. She always encourages and supports me to get my master degree as she believe this will bring beneficial change and add value to my life and career. 


\section{TABLE OF CONTENT}

ABSTRACT

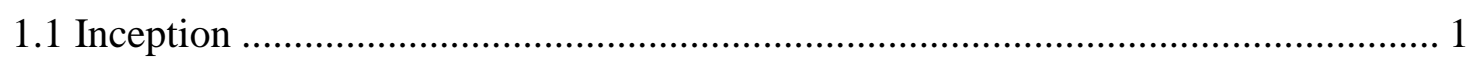

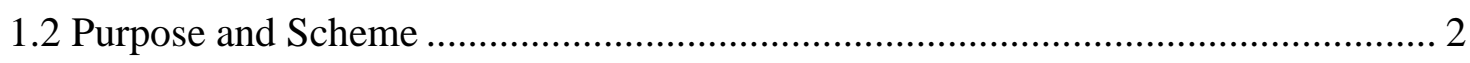

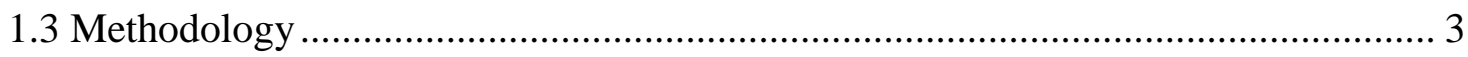

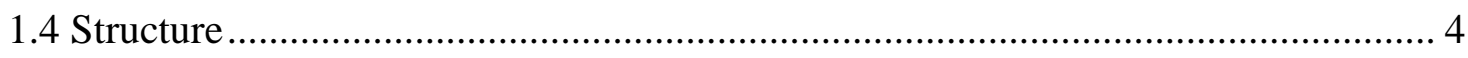

2 PHILOSOPHY OF LAW IN ISLAM AND PRINCIPLES OF ISLAMIC

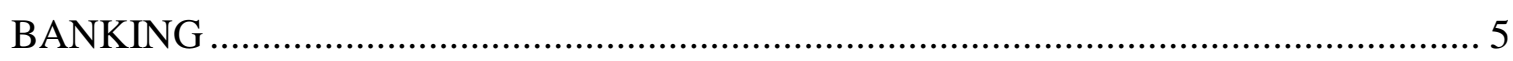

2.1 Foundation of Legal System in Islam ............................................................ 5

2.2 Introduction to Economic System in Islam.................................................. 7

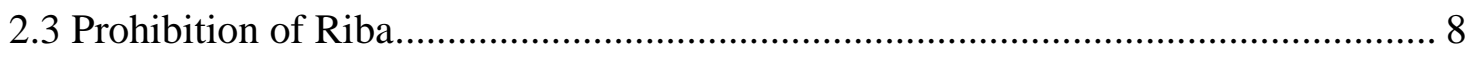

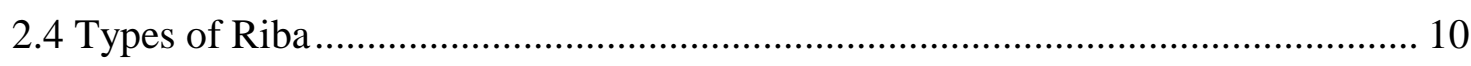

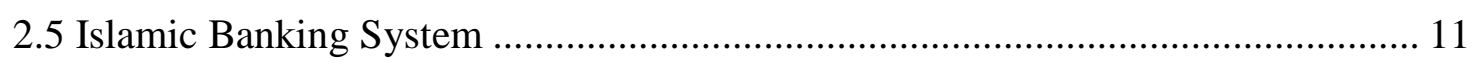

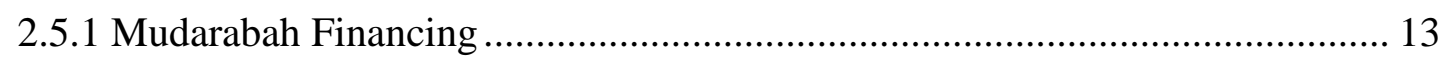

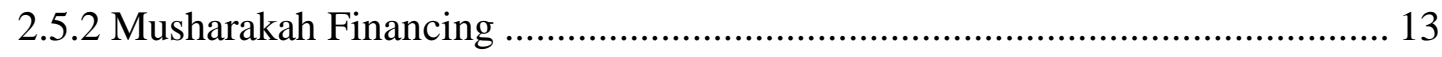

2.5.3 Ijarah (Leasing in Islamic Banking) ........................................................ 14

2.6 Combination of Islamic banking and conventional banking .............................. 15

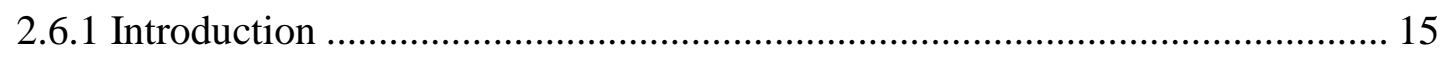


2.6.2 Similarities and Differences in Islamic and Conventional Banking 16

2.6.3 Deposits 18

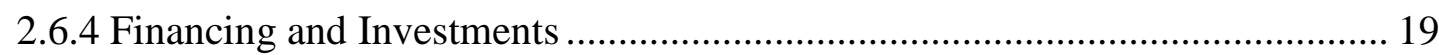

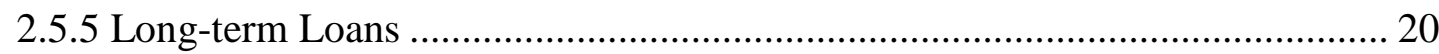

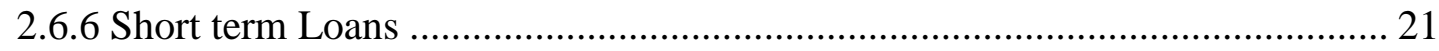

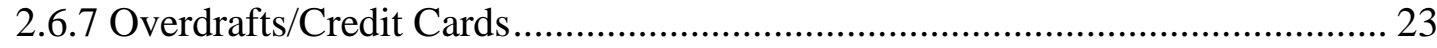

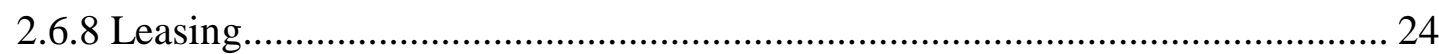

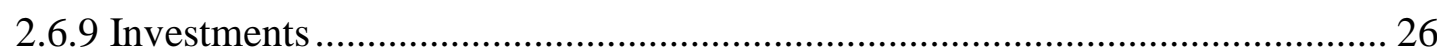

3 ISLAMIC BANKING IN MUSLIM AND NON-MUSLIM COUNTRIES ................. 27

3.1 Islamic Banking in Non-Muslim Countries (Europe and the West) ...................... 29

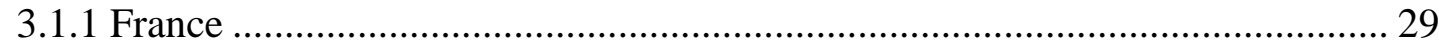

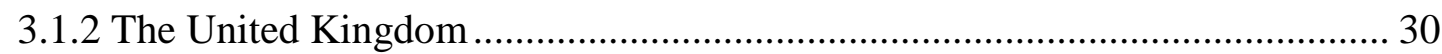

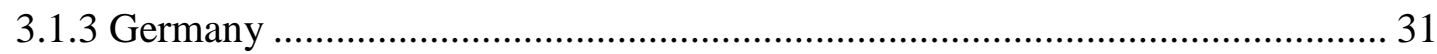

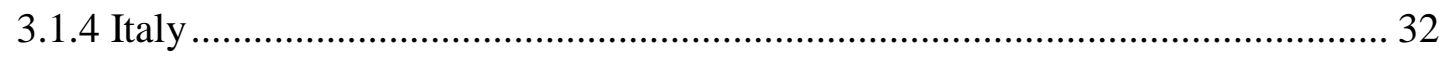

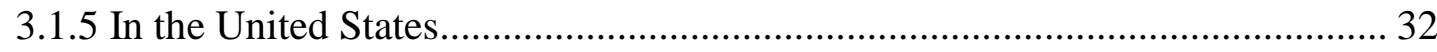

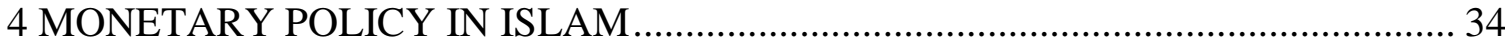

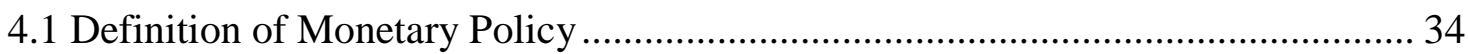

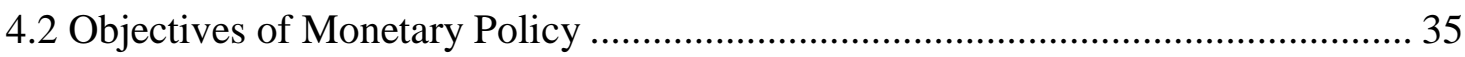

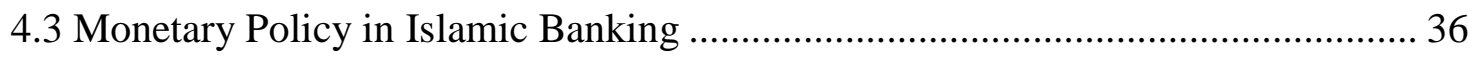

4.4 Monetary Policy Tools in Islamic Economy …............................................. 37

4.5 The Effectiveness of Monetary Policy Tools in Islamic Economy and the extent of its use as an Alternative for Conventional Economy Tools 43

4.6 The Assessment of the Effectiveness of the use of Monetary Policy Tools in the Islamic System 44 
4.7 Monetary Policy Tools in Islamic Economy Alternative to Conventional

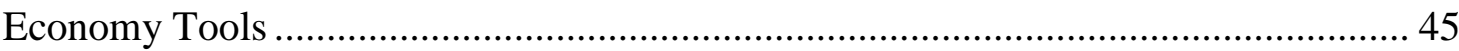

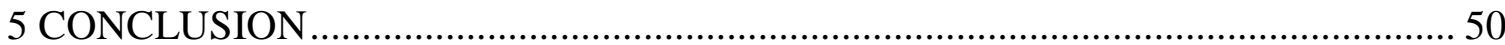

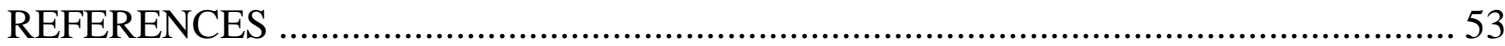




\section{LIST OF FIGURES}

Figure 1: Principles of Islamic Banking and the main four resources of Islam................. 7 


\section{LIST OF TABLES}

Table 1: Banks Offering Islamic Financing in London (Wilson, 2000)... 31

Table 2: Alternatives to monetary policy tools in positive economy from Islamic economy 45 


\section{Chapter 1}

\section{INTRODUCTION}

\subsection{Inception}

There are numerous factors led me to decide to stress on Islamic banking and finance. The most important one is that I am intending to look at new challenges in banking and finance and how to get over particular financial obstacles and difficulties. That is why I choose Islamic banking and financial system, which is becoming widespread in these days. It is unusual for the Western world to make the financial system subject to religious prescriptions. The conviction that worldly affairs and religious have to be separated particularly when it comes to finance and politics is deep-seated. People from secular states look skeptical to Muslim majority countries like Saudi Arabia or Pakistan having a state religion. After years of conventional banking (banking based on interest) Muslims are paying more attention and showing more interest for possible investment and financing activities that are in compliance with their true religion. Shariah (Principles of Islamic law) is respected by those secular countries when they are handling banking or financial issues. In United States and Europe, Muslims faced obstacles and problems when they were in need to financial services. These obstacles took place due to lack of Islamic banking services and products. During the last decades, many countries from west and east inhibited mostly with Muslims population, has started to use new banking products, which meet and match their religion principles. This style of banking system (Islamic banking) has dynamically been exploited in industrial and developing countries like Arab Gulf countries, Malaysia, Indonesia, Pakistan and most interestingly numerous EU countries like 
England, Germany, France and Italy. Those countries have started to take advantage of Islamic banking products and services via opening new Islamic branches to an existed conventional bank. Several market actors in Europe meet the increasing demand for Shariah compliant products and services. For example, England became the most important center in Europe for Islamic banking and finance, in addition to that, home to the first fully-fledged European Islamic banking and finance and to various Based-Interest banks offering Islamic financial services. Governmental authorities have supported these actions. In France and Germany, industry professionals propose that the financial institutions in EU should target Muslim groups through delivering respective offerings.

After the financial crisis, banks' clients and customers asked for more credibility, transparency, and ethical behavior. These values are deep-rooted in the banking system that is in compliance with the Shariah. Accordingly it is rational to promote financial institutions in EU to provide Shariah-compliant financial services and products to the local markets. Islamic banks are providing new service and products that continuously raising their existence in markets around the world. Right now, the numbers of Islamic Banks are increasing with the time and the assets values are growing around the world.

\subsection{Purpose and Scheme}

The objective of this thesis is an attempt to clarify Islamic Banking and finance and to determine if that new type of banking and finance can be practical in the market. Moreover, can that type provide alternative solutions for handling financial issues and problems? To be more accurate, objectives are listed as follows:

1. Clarify Philosophy of law in Islam and Principles of Islamic Banking. 
2. Introduce the Islamic financial system and institution.

3. Introduce the main differences between Islamic banking and Conventional banking.

4. Show how Islamic banking can work in non-Muslim countries.

5. Explain Monetary policy in Islamic Banks.

\subsection{Methodology}

I will depend mainly in my thesis on a descriptive analysis, which based on practical and theoretical observation of Islamic banking and finance. For example, principals of banking and finance and Islamic Jurisprudence (Shariah law). I will research the differences between Islamic and Conventional banking systems. Moreover, my thesis will introduce and discuss the Legal and economic system in Islam as well as the Combination of Islamic banking and conventional banking. My thesis is not only related with the Muslim community while also touch on and research the need for Islamic banking in non-Muslim countries. It will also concern with the financial needs and the available financial and banking products and services in the global market around the world. Accordingly, the Muslim communities and non-Muslim communities, the banks and other finance firms providing financial products and services in compliance with Shariah will be major points of interest. It is worth to mention that the research will lead us to draw the main themes and characteristics of the Islamic banking and finance future. 


\subsection{Structure}

The thesis will cover the following areas. Islamic banking and the ethical and religious background including but is limited to roles, principles and laws. Another part of my study is legal and economic system in Islam and Combination of Islamic banking and conventional banking. Other part will be covered in my thesis, which is the Islamic banking in Non-Islamic Countries and Islamic Financial System and Institutions. Finally the last part of my thesis I will discuss the Monetary Policy in Islamic banking and Finance. 


\section{Chapter 2}

\section{PHILOSOPHY OF LAW IN ISLAM AND PRINCIPLES OF ISLAMIC BANKING}

\subsection{Foundation of Legal System in Islam}

The Islamic legal scheme, known as Shari'ah law, has its grounds in the holy Qur'an, the religious book of Islam, and in the Sunnah, the stories of the Prophet Mohammad. The Qur'an is considered to be the "authentic word of Allah". The Qur'an is not a "code of law". The Qur'an covers areas as ethical and religious theses, history of the previous occurrences, worshipful matters, and definite permitted subjects varying from marriage, business relationships, and law breaking and punishment (Cornell, 2002).

Sunnah is activities, stories and actions said and done by the Prophet Mohammad. The Sunnah was reported as Hadith. These stories were properly written, documented, saved and communicated by his followers until this time. The most highly regarded Hadith, Al-Bukhari and Muslim, have trusty chains of transmission of the Prophet's words and deeds from the Mohammad's contemporaries, all the way via the person who documented and saved the Mohammad's Hadith. Qur'an and Sunnah are both considered as the main and most reliable sources of Shari'ah law. Accordingly, the Qur'an is the foundation of Shari'ah law and Sunnah provided clear description of laws and rules as well as show people how to apply these law and rules. As mention before the Qur'an and Sunnah are considered as the main sources of Islam Law. Qiyas 
is also considered as another secondary source along with Ijma. The Qur'an and Sunnah are two major sources, but Qiyas and Ijma are both considered as secondary sources. Qiyas is defined as the comparison to establish similarity and equality between two issues. It has four main pillars, Original case, new case, effective cause, and ruling. It is worth to mention that Qiyas is speculative, meaning that laws and rules derived through Qiyas cannot be of the same strength and authority as that of ruling of Qur'an and Sunnah (Kamali, 2003).

Ijma is regarded and considered as one of the sources of Shari'ah law after the holy Qur'an and Sunnah. As prophet Mohammad said: "My ummah will never agree upon an error". This hadith is cited as a confirmation and proof of the legality of Ijma. Ijma is defined as the consensus or agreement of Muslims scholars upon two things. Various schools of thought may define this agreement or consensus to be that of the first generation of Muslims only; or the consensus of the first three generations of Muslims; or the consensus of the jurists and scholars of the Muslim world, or scholarly consensus; or the consensus of all the Muslim world, both scholars and laymen(Mohammad Farooq, 2006).

The below figure (1) shows the principle of legal system in Islam and the main four sources of Islam namely, Qura'n, Sunnah, Ijtihad and Qiyas. 


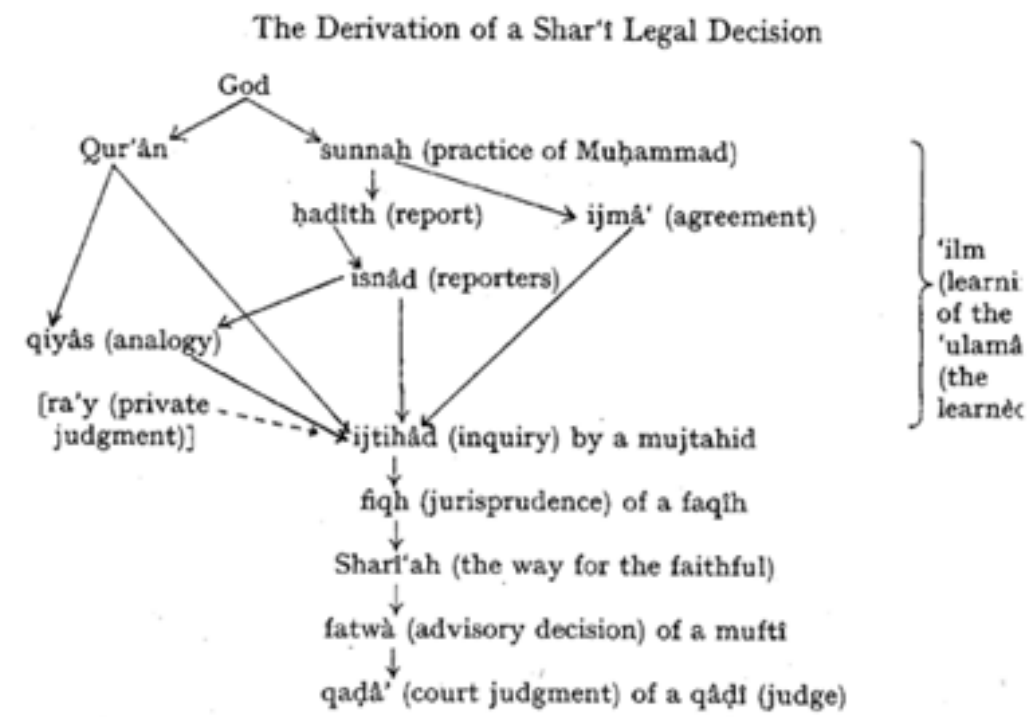

Figure 1: Principles of Islamic Banking and the main four resources of Islam

\subsection{Introduction to Economic System in Islam}

Islam has set standards, rules, regulations, policies and strategies for such economic system to be established. These standards aim at preventing the malignity that could occurs between different socio-economic sections. These standards have identified and recognized money as the most influential element in community. There is no doubts that collecting money concerns the majority of human beings who initiate and/or participate in transactions between people.

Others could think that Islamic economic system is concerned with the exact amount of expenditure, income, imports, exports, and other economic statistics. While those matters are not important as Islam is shedding the light on with the spirit of the economic system (Taqiuddin, 1997).

Islam as a religion consists of a set of beliefs and rules, which identifies and organizes the relationship between God and individual; between the person and other people; between the person and the world; even more the relationship between the person and 
himself/herself. One type of human behaviors is economic behavior, accordingly we can conclude that Islam regulates human behavior. Economic behavior for Muslims is considered as one essential and crucial mean of consumption of goods and services, distribution, and production. In Islam religion, behaviors of human beings even in the economic areas or other areas are not value free; nor are it value neutral. It is connected with the ideological basis of the faithfulness (Mawdudi, 2010).

\subsection{Prohibition of Riba}

The main issue that distinguishes Islamic finance from conventional finance activities is Riba. It is the most debatable and the most crucial issue that have widely applicable effects in Islamic banking and finance system. In the meantime, clarification and application of Riba is the main topic to many discussions throughout the world. Riba (usury) means increasing, growing, accessing, adding, or merely prohibited gain. It could also be defined as "earning money without providing an inverse value" because of that, additional money is forbidden according to the Holy Qur'an and Sunnah. Most of the Muslims around the world believe that Qur'an prohibited the taking or paying of any extra or additional money to the principle money. In Islamic word there is an essential difference between earing money from commercial activities and earing money from lending loans. As Allah said in the Holy Qur'an on the prohibition of Riba: 
"Those who consume interest cannot stand \{on the Day of Resurrection\} except as one stands who is being beaten by Satan into insanity. That is because they say, "Trade is like interest. But Allah has permitted trade and has forbidden interest". So whoever has received an admonition from his lord and desist may have what is past, and his affair rests with Allah. But whoever return to [dealing in interest]-those are the companions of Fire, they will abide eternally therein. (Surat Al-Baqarah from Ayah 275) $”$.

Moreover, Allah said also in the Holly Qura'an to those who take and deal with Riba are at war with almighty Allah and Prophet Mohammad because, Riba prevents the wealth of Allah's blessing and encourages the illegal appropriation of property belongs to others and harms Muslims' welfare. So that, in borrowing and lending only the principal money must be repaid without any additional money like interests.

"You who have believed, fear Allah and give up what remains [due to you] of interest, if you should be believers. "(Surat Al-Baqarah from Ayah 278).

"And if you do not, then be informed of a war [against you] from Allah and His Messenger. But if you repent, you may have your principal-[thus] you do not wrong, nor are you wronged." (Surat Al-Baqarah from Ayah 278).

Riba has been prohibited by the God as the fourth sin of the seven heinous sins after Believing of other Gods, Magic and Murder (Seven heinous sins (Al-Saba al-Mubiqat that hadith from Prophet Muhammad)). Mohammad also said in his farewell sermon: "God has forbidden you to take Riba, therefore all Riba obligation shall henceforth be waived. Your capital, however, is yours to keep. You will neither inflict nor suffer 
inequity. Mohammad cursed the one who deals with Riba (Receiver, payer, the one who records it, and the two witnesses to the transaction) and said: "They are all alike in guilt. Mohammad also stated that dealing with Riba is worse than Zina, worse than to a man committing Zina with his mother.

\subsection{Types of Riba}

According to Sunnah, there are two types of Riba. Riba Nasiah and Riba Al-Fadl. Riba Nasiah means defer, delay or wait. It is related to "money-to-money exchange"; which mean the time that is giving to the borrower to pay back the loan in return for addition or extra money. Shariah scholars do not record this generated interest from time period as an asset constituting value. All those additional or extra money resulting from granting more time (delay) to pay back the loans is not allowed as no reverse value is given (Chapra, 2006).

Riba is not only limited to money while it includes transactions in which the debtor returns a sum of goods above the original transaction, be it money, commodity, any other item or goods or services; anything in excess of the original agreed agreement is considered as Riba if items exchanged are of the same type (For example, Silver for Silver) (hadith). That is the second form Riba. Riba Al-Fadl is an Arabic word, which means growth or increase. Riba Al-Fadl refers to all hand-to-hand exchanges. It is required that "commodities are exchanged for barter instead of cash since there may be differences in the quality of the goods" so that an "unfair increase, being Riba" could emerge (hadith). 
Risk sharing: Because of the prohibition of interest, the fund's suppliers prefer to be investors instead of creditors. Islamic Banks and institutions that provide financial capital are sharing business risks and profits with their customers.

Prohibition of speculative behavior: An Islamic banking system discourages hoarding and prohibits actions and transactions including gambling, risks, and extreme uncertainties.

Contracts Sanctity: Islam respects contractual obligations and agreements also the exposure of information and data as a sacred obligation. This feature is purposed to decrease the asymmetric information risks and moral hazards.

Shariah-approved transactions: Only those business transactions and activities that do not break the rules of Shariah law for investment. For instance, any investment in businesses dealing with gambling, casinos, and alcohol would be prohibited (Zamir, 1997).

\subsection{Islamic Banking System}

Under Islamic system, activities of banking will certainly be more complex and varied, when compared to the activities in the system of conventional banking. In profit sharing basis, the standard of the borrower's credit-worthiness that underlies conventional banking systems will have to be changed to be more emphasis on the profitability and viability of the particular business being proposed. Moreover in structure of rates of return term, banks should consider structure rate of returns would be for different economic actions and activities. Appraisal and evaluation for the project, estimating profit and loss sharing percentages, processing, establishing a business structure for the strategies of managing, administration, auditing, controlling of other businesses what will increase the demand of commercial banks. On the part of liability, by using profits and dividends basis bank attracts customers and 
depositors, not via interest rates. Briefly, transformation of the commercial banks under Islamic system should occur, and have to be transformed into Islamic institutions that would act as if they were investment banks in Western financial systems. In an Islamic system structure the monetary authorities regulate and organize financial and banking operations in the economy in purpose of allocating resources in accordance with the society's priorities, and directing monetary policy towards special goals.

The supply of high-powered money controlled by the central bank, the reserve ratios on the different types of liabilities, to accomplish its policy objectives, and the highest asset amounts that banks can distribute to their activities of profit sharing. Another chance is available for rising the authority in the baking system for the central bank through its collecting of banks and various financial institutions equity shares. Central bank can increase its impact on the financial system by enhancing its managing abilities, administration, and regulatory, in addition of its lender-of-last-resort role. In addition to that, opportunities will be available to invest in the basis of profit sharing instantly in the real sector by central bank, and with the company of other financial institutions and banks, central banks will have the chance to hold equity positions in joint ventures. Central banks will have the ability to trade securities in the market depending on several conditions, such as not having a non-zero coupon rate and not having a par value structures.

Lending operations or banks: Islamic banks apply profit and loss sharing basis in their loans transactions and activities. Mudarabah and Musharakah are the both methods that fulfill the requirements of Shariah on the lending part. Both forms are 
basically included in the partnership agreements for which parties share profit and risk.

\subsubsection{Mudarabah Financing}

In Mudarabah transaction, the owner ( $\mathrm{Rab} \mathrm{Al} \mathrm{Mal}$ ) provide surplus funds to another party (Mudareb) to be invested in a productive economic action for agreed percentage (Predetermined in the contractual agreement) of the earned profits. During the project cycle, the lender is the only owner ( $\mathrm{Rab} \mathrm{Al} \mathrm{Mal}$ ) of the project while the borrower is the manager (Mudareb). Profits will be shared between both Rab Al Mal and Mudareb, but in case of losing, Rab Al Mal is the only party who take the whole risk of any financial losses while Mudareb only loses the effort and time spent in the project. In Mudarabah rules, financial institutions and banks would offer loans to projects, but instead of charging interest, they share profit earned by Mudareb. Banks can indirectly provide loans via firms set up specifically to involve in Mudarabah financing activities. Using Mudarabah financing form, however, the banks provide all the capital needed to fund it, either through loans or in direct equity form. As a result, the bank on the other hand will receive a written document as an agreement contract showing the face value of the commodities of Mudarabah mentioning the details of the financial transactions, those contract can also be traded between banks. The Mudarabah can either finance a single firm with a specific purpose, or a multipurpose firm including various activities, is required and permitted under the Islamic law which is referred as Shariah. In addition, however, Mudarabah can also have an effect in non-financial activities and project (Ahmad, 1987).

\subsubsection{Musharakah Financing}

Musharakah operation, which is complementary to Mudarabah financing, more than one contributor of funds in the investment capital. All parties involved in Musharakah 
invest in different proportions in the investment capital. Profit is predetermined while losses are shared carefully in relation to the parties' contributions in the investment capital. Number of involved parties in the agreement is the key difference between both Musharakah and Mudarabah. In fact, Musharakah form closely corresponds to an equity market in which shares can be obtained by the banks, government, public, and central bank. Since profit and loss from Musharakah agreement will not be in the initial financial investment known, these financing forms comply with Shariah. Companies needing to increase funds for investment could simply use the technique of Musharakah and offering Musharakah agreement in the market (Usmani, 2002).

\subsubsection{Ijarah (Leasing in Islamic Banking)}

Ijarah or Islamic leasing is defined as an agreement between two parties that allows one party (the lessee) to use an asset owned by another party (the lessor) for an agreed/fixed price over a specific period of time. Ijarah is a type of asset finance that has the benefit of using assets without the need to own the asset and without transferring the ownership of the asset to the other party.

Islamic Banks and Financial Institutions use ijarah agreements as a lessor (Owner) or a lessee (Other party/Renter). As for the ijarah agreement to be valid owning the asset to be leased by the owner should precede it. The ijarah agreement is considered as a binding agreement for which neither party may amend or cancel the contract without the other's approval.

In the Ijarah agreement, the duration should be defined and included in the contract and normally start on the date of executing the agreement unless a future date is confirmed by both parties. The Islamic bank requires the client to pay in order to guarantee the client's commitment to agree on a lease of the asset and the subsequent 
obligations, on other hand, no deduction to be made to this total sum except for damages suffered by the bank. No rental is due unless the lessor is not able to deliver the asset to the lessee on the agreed date in the ijarah agreement. When the Ijarah contracts came to an end, the renter has three choices as follow:

- Return the rented asset to the owner.

- Renew the lease agreement for another form.

- Purchase the rented asset.

More on the leasing contracts, the renter is committed to compensate the owner for every harm to the rented asset caused by any negligence or misuse. The rented asset shall remain in the risk of the owner during the lease period (Ameer \& Ansari, 2014).

\subsection{Combination of Islamic banking and conventional banking}

\subsubsection{Introduction}

This part is an attempt to identify and agree on the similarities and differences between Islamic and Conventional Banking and finance. Based on several studies and researches, in the last decade Islamic banking and finance was more like a modern conventional banking with particular Shariah restrictions on products and services. It has been also confirmed by several studies and researched that Islamic and conventional banking are not same, meaning that there are major differences between both in relation the operations of Islamic Financial Institutions if it's compared with conventional banking. Islamic Banking and Finance Institutions was successfully able to gain and create trust of Non-Muslims' and Muslims' clients and customers by using the basis of sharing loss and profit while the availability and access to options of financing and investment to Islamic institutions and banks are restricted however in conventional institutions and banks the situation is not the same. 
Liberation of Muslim world during the 20th century from colonial authority's nearly accomplished and Islamic philosophy paved its way in Muslim communities by which the crowds started to shed the light on and looking at the social systems and addressed amendments, improvements and developments. The Muslim scholars and thinkers faced several obstacles in relation to the domination of social systems, overcame these obstacles and go beyond their shortcoming.

Capitalism was inspected in detail because of its acceptability and magnitude in many communities across the world. Depending in that system, bank is the major trader of money; and charge interest for using that money; so the main fountain of income to conventional institutions and banks is taking interest via money lending and deposits accepting it for interest respectively. Operations of conventional institutions and banks are based on charging interests while other products and services are performed and completed for reward and considered as essential portion of revenue of institutions and banks. Since the conventional institutions and banks are founded under the basics of charging interest which is forbidden in Islam religion (According to Shariah), Muslims' choices were limited to start their Islamic financial institutions and banks according to Islamic principles.

\subsubsection{Similarities and Differences in Islamic and Conventional Banking}

Islamic and Conventional banks and institutions are running and operating in the same societies and communities and perform all of its functions that are expected from a financial institution. Islamic institutions and banks are providing assistance to businesses across the world by making all the services and products needed to smoothly run the economy available, however, major differences in relation to the operation and philosophy are identifies. In this part I will go over the analysis of 
actions, services and commodities of Islamic institutions and banks in comparison with those provided by conventional institutions and banks. The main expectation of any financial system is to provide proper assistance in smoothly running the economy by making the following services and products available. The first one is the mobilization of savings between savers and entrepreneurs while the second one is the provision of utility services and products including but is not limited to international trades facilitation, funds transfer, consultancy services, and another duty for a fee. Islamic banks do not restrict the provision of such services and Institutions as long as performing those services is not prohibited by Islamic law. However there are major differences in relation to the funds mobilization mechanisms between savers and entrepreneurs. Saving mobilization compose of two main parts, the first one is accepting deposits and the second one is extension of investment and financing. 


\subsubsection{Deposits}

Collecting deposits from savers under both Islamic and Conventional bank and is done and performed for reward regardless if the bank is operating under Islamic or conventional system. The difference is directly related to reward taking. Reward via conventional banking is predetermined and fixed but reward via Islamic banking is taken through Mudaraba and Musharaka where reward is not fixed (Considered as variable). On the other hand, return amount under conventional banks affected with the time, it is higher in the deposits for long term and lower in the deposits for the short term. The same is applicable in Islamic banking to share profit with depositors. Long term deposits available for longer-term bank investments meaning higherweight profit sharing and vice versa. One main difference between conventional and Islamic system lies in profit and loss. The total risk in conventional system is born by the financial institution or the bank and total profit belongs to the financial institution or the bank after fixed-rate depositors' servicing while in Islamic system both profit and loss are shared. Profit of depositors is related to investments earning's by IFI (Cevik \& Charap, 2011).

Islamic banking is acting as the client's agent or representative when dealing and working with this deposits accounts. Under Conventional banking, the situation is completely different since the bank is acting as the debtor as the conventional bank is paying interest (Riba) for clients who have deposits accounts. On other hand, Islamic bank is investing the money of the deposits accounts in order to make suitable profit and share profit and loss with depositors after excluding managerial expenses. Under Islamic banking, it is possible that the client can make profit and / or loss money. As for clients who have deposits accounts under conventional banks, possibilities to lose 
money is very limited since the agreement is to pay fixed interest to the client regardless to the amount of lose or profit made by the conventional bank. Under Islamic banking, deposits investment is done according to Shariah law as long as it is not used on noncompliant-Shariah things (Prohibited by Islam Law). A special committee supervises all transactions initiated and processed by the Islamic banks. Under Conventional banking, noncompliant-Shariah investments are possible specially charging extra-interests/Riba during borrowing and lending. Accordingly, Islamic banking in this point is highly recommended comparing with the conventional banking since it is based on profit and loss sharing base and the risk is shared between the bank and clients then the risk or the loss will be lower comparing to conventional bank as the total risk in it born only by the bank. In addition to that, Conventional banks depend mainly on borrowing money of depositors to individuals, companies, governments, and institutions and charge them fixed-interests.

Under Islamic banking, banks invest deposits commercial, agricultural and industrial projects that could serve the community since the Islamic banks cannot charge interest because Islam has prohibited Riba. In relation to this point, Islamic banking seems to be not recommended because the profit is fixed without risks under conventional banking. Under Islamic banking, bank will invest money in different projects. The project might make profit or may be loss the money. This means that the profit of the projects will be shared between the bank and clients according to profit and loss base.

\subsubsection{Financing and investments}

As discussed in the previous section, accepting deposits is one of the main differences and similarities between Islamic and conventional banking which is the first part of the saving mobilization. The second part is the extension of investment and financing 
to industry and business for reward. Islamic and Conventional banks are both offering finance activities to customers and clients for reward. The difference between both Islamic and conventional related directly to financing agreement. Islamic banks cannot offer loans for fixed reward as they cannot charge interest, while this could happen in conventional banks since they can charge interest and offer loan for a fixed reward. Islamic banks and institutions can only get profit from investments but they cannot charge interest as conventional banks from loans. It means that they are offering products not money. In Islamic banks the only loan that can be issued is Qard Al-Hassan (Free interest loan) while in conventional banking there are three different types of loans that can be issued to clients, namely, long-term loans, short-term loans, and overdrafts.

\subsubsection{Long-term Loans}

Those types of loan issued for building or purchase of fixed assets (For example, Plant, property, or equipment) by companies to maintain or expand existing assets. Islamic banking system is offering Bai Muajjal, Murabaha, and Istasna for individuals and firms instead of long-term loans. As well as, another financing long-term financing option is profit sharing through Musharaka and Mudaraba. Despite that financing under Murabaha, Bai Muajjal and Istasna look like loans issued by conventional banks with one major difference related to the providing of asset and not money (Cash) to customers while the other exist in the financial agreements which change and shed the light on the nature of returns and risks. Islamic Banks and firms consider financing under Mudaraba and Musharaka as one key challenge. Financial agreement should be clear enough and cover risk of losing the amount (It should be involved in the agreement) accordingly; Shariah-compliant firms have to get approval 
on the profitability or viability of the business to the fulfillment of Islamic Banks (Hanif, 2011).

\subsubsection{Short term Loans}

Conventional banking systems are offering short and medium term loans to clients in order to achieve their working capital required to the firm day-to-day operations. Working capital is required for inventories investments, accounts receivables and cover the expenses. Regarding covering day-to-day expenditures of business is offered via certificates of participation duration by gaining profit in a particular period and shared by Islamic banks on prorate basis. Under conventional banks, financing via participation terms are more complex than short-term loan because of the risk involved for Islamic banks in the transaction. Firm seeking short-term facility from Islamic banks has to verify the viability of the project to the satisfaction of investor. Islamic banks are also not provided personal consumption loans however any person through Mudarabah financing can obtain his needs or anything for his personal use, as a result the Islamic banks will add a particular percentage of profit depending on the amount that is being obtained. In Islamic financial system in default Islamic banks cannot borrow cash for interest (Only Charity loan - Qard Al-Hassan). One advantage of Mudarabah is that it does not charge extra money as time value increases like conventional banks. However, Mudarabah can sometimes charge penalties that were already mentioned in the agreement contract, but of course those penalties will not be specified as income for Islamic banks. Those penalties will be for charities (Awan, 2009). However, Mudarabah is not a non-benefit form of finance, although it doesn't depend on paper money as its utilities, but it has other sources of utilities such as through products and services. Yet, there are precise differences that exit within the two form of Mudarabah financing, although it is being used effectively and efficiently 
and have gotten ahead in meeting the requirement of short term goals. The two form of Mudarbah financing as follows:

- Under Murabaha the product is a goods and services not cash.

- Asset firstly bought by Islamic banks and then sell it to customer hence Islamic banks share in risk.

- Under Murabaha refinancing facility does not exist.

- In the default cannot increase the commodity's price however penalty if stipulated in the agreement may be imposed of Murabaha but cannot be involved in Islamic banks income.

- In Islamic banks only dealing with assets that are not against with Shariah.

Musharaka is an efficient way to eliminate and bridge the gap on the relationship between the return of the capital and reward of effort. As a justification of choosing this type of agreement is that it elaborate the contradiction and dispute between Islamic and Conventional Banking since the Conventional banks finance projects via loans and charging interests regardless to the projects results and without taking any responsibility by the bank or depositors. Meaning that if the project has no return and did not achieve any results then borrowers are committed to pack the loan amount including interest. However, application of Musharaka depend mainly on sharing responsibility and risks between the bank and investors in a fair manner. They all share the consequences and results of projects including risk, profit and loss. This is not followed by and applied in Conventional Banking Systems where responsibility is only taken by investor since he/she is the only one who take the profit, loss and risk. As a result of the previous clarification and explanation, Musharaka is built on risksharing base where investor take reasonable profit and should accept loss in contrast 
in case if it failed to achieve expected results and returns. It does not mean that investor will not take fixed reward for the invested money given that profit and loss is not expected in the beginning even if it has been agreed that risks will be very limited during the in-depth study of the project. Accordingly, Musharaka share profit and loss between banks and clients as well share positive and negative results. This makes Islamic banking financing as actual finances since it contribute fully to projects implementation and practice commercial and financial processes. On other hand, Conventional banking remains in isolation from risks exposed by debtor. At the end, conventional bank get the money back including interest regardless to the profit or loss of which is prohibited in Islam.

Musharaka force banks and clients to conduct thorough analysis and appraisals of projects in order to carefully and accurately estimate returns. This requires the utilization of all available technical expertise, accordingly the cost will increase. Conventional banks only offer funds or loans without involving in projects implementation and regardless to either positive of negative results. Moreover, Muskaraka contribute to the social and economic empowerment and development through the distribution of wealth. Under Musharaka, Islamic institutions and clients contribute to the establishment of a balance where negative and positive results are taken by and fairly shared between the bank and the clients. Unlike Conventional banks, where clients and customers are only offered loans including interests. The loans are offers to clients from the bank deposits and small percentages are given to depositors from the total revenue / returns.

\subsubsection{Overdrafts/Credit Cards}


Overdrawing from the customer account on interest is one of the facilities that is offered by conventional banks. Credit cards are one of its forms where the limit specified to the customer by the bank. Credit cards provide customer with a dual facility including financing such as plastic money facility where the customer can cover his expenses without carrying money.

Islamic banks do not offer the facility of financing except in the shape of Murabaha, meaning that Islamic banks only deliver the required goods but not cash/money while facility to cover expenses and fulfil requirement is offered via debit card where the client can use his own card. In conventional banks, client is required to pay interest while in Islamic banks, customer (Under Murabaha) is requested to pay profit when the customer receive his commodity. Under Conventional banks extra charging is allowed when default customer exceeded the agreed period however this is not allowed under Islamic banks (Under Murabaha).

Under Conventional Banking Systems, customers are allowed to reschedule by involving into a new agreement to pay interest in case of exceeding the extended period however this is not the case under Islamic Banking Systems (Under Murabaha). Islamic banks can only demand the original amount specified in the initial agreement. Different case in Murabaha is how to treat with international debtors. Several options are available under Islamic banks to deal with international defaulters including blacklisting defaulters for anymore financing ability, to include in the agreement that in if they could not pay all payments will be due at once, and also to include in the agreement a penalty should be provided while cannot included in Islamic Bank income, it will be for charity purposes (Eisfeldt \& Rampini, 2005).

\subsubsection{Leasing}


A lease is an agreement between the lessee/user to pay the lessor/owner for the use of an asset. The ownership of leasing agreements can be or cannot be transferred according to conventional banks policies. Islamic banks are also offering leasing called contract of Ijara. Through agreement of Ijara assets are offered to clients for use with keeping the ownership to the bank that means the ownership is not transferred to the other party of the agreement in a specific time-period of time. After the completion of lease term, transferring the ownership of asset to client can be under another arrangement and contract. Islamic bank is the only party that takes the risk under Ijara agreement in order to keep the ownership for the bank (Shams, 2011). There are major differences between Islamic and conventional banking systems under leasing/Ijara agreement can be summarized as follow:

- Under Ijara agreement, rental is not due until delivering benefit to client for use.

- Extra rental amount cannot be requested if the lessee cannot pay since it is not included in the agreement.

- Lessee is responsible for major repair or any maintenance activities of the asset during until the agreement come to an end between lessee and lessor.

- Risks of ownership are only taken by Islamic bank. In other word, if the asset is destroyed or lost Islamic bank cannot claim extra money from lessee. 


\subsubsection{Investments}

Conventional Banks have many ways to keep liquidity, including government bonds and shares, shorter term loans, money at call, investment in shares, and leasing companies' bonds, etc. Interestingly maintenance of mandatory reserve between conventional banks and central banks is also depending on interest. Central bank also providing liquidity to support commercial banks in rainy days for interest. Issuing bonds against banks' receivable is also way for create liquidity in conventional banks. For Islamic banks ways in liquidity creation are very limited. Islamic banks cannot invest in short term loans, government securities, money and bonds at call and short notices because those transactions are based on interest. Mandatory reserve with central bank maintained by Islamic banks but they are not depending on interest as conventional banks. On interbank deposits Islamic banks cannot request interest. Freshly Islamic banks have created a way to meet their required liquidity by using Islamic bonds (Skuks). Servicing in Skuks is fixed similar to bonds in conventional banks however some kinds of Skuks can be issued against Ijara receivables. Firstly in IjaraSkuks asset is given on rent to the client for specific rentals and period but the ownership of asset remains with Islamic banks. To meet required liquidity Islamic banks issue Skuks in the market to the investors at equal to the asset's value, and then ownership of the asset will transfer to Skukholders (Hanif, 2011). 


\section{Chapter 3}

\section{ISLAMIC BANKING IN MUSLIM AND NON-MUSLIM COUNTRIES}

During the last decades, Islamic Banking has been one of the major topics. Islamic banking is viewed as a model that could challenge the powerful conventional banking systems. Islamic banking has been dramatically growing globally at stunning rates. In other words, Islamic banking has gone from nothing to and new industry with assets of billions of dollars. In a global level, these assets have reached and exceeded USD one trillion. In the meantime, customers, in large parts of Asia, the Arab world, and Muslims in the west are interested in and significantly attracted by the Islamic banking model that match their believes. Giving that Islamic banking are located and set in Muslims countries, Islamic banking services are now offered in non-Muslims counties. Numerous numbers of conventional banks opened Islamic departments for which these departments are not completely independent institutions while it offers and provides services and products that comply with the Islamic Shariha. HSBC (Hong Kong and Shanghai Corporation), American Bank, Deutsch Bank, Citibank, American Express Bank and Union Bank of Switzerland are examples of conventional banks with Islamic departments and windows. During the last decades eastern along with the western countries has started to use new banking products that matches their cultural and religious values. Islamic banking has actively been exploited in fast developing and industrial countries like Arab Gulf countries, Indonesia, Malaysia, and some of the European Union countries like France, Germany 
and England already included and integrated Islamic services and products into modern banking sector. Muslims in non-Muslim countries faced problems and certain issues in the past when they were in need to financial services and products. These problems and difficulties including but is not limited to investments, savings and mortgage occurred because Islamic banking in these countries was not existed. The situation has dramatically changed in the last decade. Islamic banking is more accessible in the non-Muslim countries (Azami, 2011).

In the mid of 1940s, the first Islamic Experimental Islamic bank was instituted by Malaysia while in 1950s to 1960s, Pakistan and India established the first experimental Islamic-banks. Egypt instituted the first Experimental Islamic bank which considered the first experiment in the Arab world (In 1963, Egypt's MitGhamr Savings Bank) and (In 1971, Nasser Social Bank). In 1970s the wake of oil-wealth and the high-energy price promoted and encouraged the expansion of both Islamic and conventional Banks. This has a significant impact to many institutions to contribute in the economic and social development of the Gulf Region. By 1975s, Dubai established its first Islamic development bank. In 1979, Pakistan became the first country to Islamic banking practices at the state level. In 1980, more academic institutions and Islamic banking emerged in several countries. Pakistan (In 1977), Iran (In March 1984), and Sudan (In July 1984) announced their intention to transform their financial systems to be in compliance with Shariha principles and rules. By 1983, Malaysia instituted its first bank that is in compliance with Shariha (Bank Islam Malaysia) and Sudan reforms its banking system on Islamic principles. In 1980s, two groups of companies were established (Dar Al Maal Al Islam in 1981 and Al Baraka group in 1982) which considered a very important development. Dar Al Maal Al 
Islam was established in Bahamas, the headquarter in Geneva and operates 10 Islamic banks, 7 Islamic investment companies, 7 trading companies and 3 Takaful (Islamic Insurance) companies in 15 countries around the world while Al Baraka group was established in Saudi Arabia in 1982 and has activities in around 43 countries. It has more than 2000 companies including but is not limited to 15 Islamic banks and several Takaful Islamic insurance companies. In 1991, Indonesia established the first officially sponsored Islamic Bank (Kahf, 2005).

\subsection{Islamic Banking in Non-Muslim Countries (Europe and the West)}

\subsubsection{France}

In December 2007, Paris EUROPLACE instituted the Islamic Finance Commission. Since then, the French financial markets regulator has issued two placed enabling Shariah compliant law and rule investment Sukuk listings and funds. Paris stock exchange has produced Sukuk and four tax rules In relation to Sukuk, Murabahah, Istisna, and Ijarah and they have been announced as a tax treatment with conventional financial products. Government has taken several steps to support and promote Islamic banking in the country. The first initiative, which included regulatory and tax changes aimed at enhancing and supporting Islamic banking in France, was announced in July 2008. These changes are related to the admission to Sukuk listing on a French regulated market, the tax treatment of Islamic financial transactions and, to a lesser extent, reforms of the French trust. In July 2010, the French authorities made changes and adaptations to its laws to smooth the process of issuing sukuk. In June 2011, France started to opened Islamic banking windows from an existing conventional bank. The main reason behind these successful steps on lunching Islamic branches is that the majority of the French population is from Algeria, Tunisia and Morocco (Mauro, 2013). 


\subsubsection{The United Kingdom}

The Islamic financial market in UK is considered as the most advanced market in Europe and becoming rapidly a key target for foreign Shariah-compliant institutions. In the 1980s, Islamic banking and financing actions have started in England when the London Metal Exchange, which the world center for industrial metals trading, have offered overnight deposit services in compliance with Shariah based on one key Islamic banking and finance principle which is Murabaha (Wilson, 2000). Introducing Islamic mortgages (based on the Murabahah principle) by institutions from the Gulf Cooperation Council by 1990s and providing mortgage financing (based on the Ijarah principle) was the first application and integration for Islamic banking and finance in the UK market (Caristi, 2013). By 2013s, the United Kingdom authorities invented the first Islamic Finance Task Force. This task force will promote the development of Islamic banking and finance sector in UK and will increase investment as well as strengthening their economy. On other hand, the task force will enable UK to play pivotal role in applying Islamic banking in Europe markets (Wilson, 2000). 
Table 1: Banks Offering Islamic Financing in London (Wilson, 2000)

\begin{tabular}{|c|c|c|}
\hline Bank & Operation & Activity \\
\hline ANZ International & $\begin{array}{l}\text { Islamic Banking } \\
\text { Department }\end{array}$ & $\begin{array}{l}\text { Trade finance investment, } \\
\text { leasing }\end{array}$ \\
\hline Al Rajhi Banking & $\begin{array}{l}\text { Representative Office of } \\
\text { Saudi Arabian registered } \\
\text { bank }\end{array}$ & $\begin{array}{l}\text { Trade finance investment, } \\
\text { leasing, project finance }\end{array}$ \\
\hline Citibank International & Corporate finance & $\begin{array}{l}\text { Trade finance investment, } \\
\text { leasing, project finance, } \\
\text { financial engineering }\end{array}$ \\
\hline $\begin{array}{l}\text { Dresdner Kleinwort } \\
\text { Benson }\end{array}$ & $\begin{array}{l}\text { Islamic Banking } \\
\text { Department }\end{array}$ & $\begin{array}{l}\text { Trade finance investment, } \\
\text { leasing, investment } \\
\text { banking }\end{array}$ \\
\hline $\begin{array}{l}\text { Hong Kong \& Shanghai } \\
\text { Banking Corporation }\end{array}$ & $\begin{array}{l}\text { Global Islamic Finance } \\
\text { Unit }\end{array}$ & $\begin{array}{l}\text { Trade finance investment, } \\
\text { leasing, investment } \\
\text { banking }\end{array}$ \\
\hline $\begin{array}{l}\text { National Commercial } \\
\text { Bank }\end{array}$ & $\begin{array}{l}\text { Representative Office of } \\
\text { Saudi Arabian registered } \\
\text { bank }\end{array}$ & $\begin{array}{l}\text { Trade finance investment, } \\
\text { leasing }\end{array}$ \\
\hline Riyadh Bank Europe & $\begin{array}{l}\text { Representative Office of } \\
\text { Saudi Arabian registered } \\
\text { bank }\end{array}$ & $\begin{array}{l}\text { Trade finance investment, } \\
\text { leasing }\end{array}$ \\
\hline Standard Chartered Bank & Islamic Banking Unit & $\begin{array}{l}\text { Trade finance investment, } \\
\text { leasing }\end{array}$ \\
\hline United Bank of Kuwait & Islamic Banking Unit & $\begin{array}{l}\text { Trade finance investment, } \\
\text { leasing, investment in real } \\
\text { estate including student } \\
\text { accommodation and } \\
\text { nursing homes }\end{array}$ \\
\hline
\end{tabular}

\subsubsection{Germany}

Germany is considered as one of the biggest markets for Islamic Banking and Finance. Four million Muslims are living in Germany the $2^{\text {nd }}$ highest Muslim population in Europe after France with 5.5 million, most of them are young (between 14 and 49 years old). Germany, is moving toward facilitating Islamic banking and finance in its jurisdiction. Based on a recent consultation and estimations, the 
potential of the market in Germany for Islamic Banking and Finance products to reach the amount of 1.2 billion Euro. A survey conducted in 2010 revealed that $72 \%$ of the Muslims populations living in Germany are interested in Islamic Banking and Finance products and services (Factsheet). Turkey's Kuveyt Turk investment fund, which works under the principles of Islamic shariah law, plans to establish its first branch in Germany (Hamed, 2013).

\subsubsection{Italy}

Italy is one of the most developed markets in EU. Some interesting initiatives have been started by the Italian government in order to study concerns and matters in relation to the presence of Islamic banking and finance. Some initiatives have been lunched in order to promote the possibility of launching a Mediterranean Partnership Fund, part of which would be Shariah-compliant. Those initiatives, dedicated to promoting small sized and medium sized enterprises in the MENA region through equity instruments or semi equity instruments, may involve the Union of Arab Banks, Arab governments and Islamic multi-lateral development banks since the intention to introduce a Shariah compliant component. On the other hand, Italian banks have been also active in the Gulf Cooperation Council region, especially in private/public partnerships. In addition to that, there are a some joint trade relations between Italy and Gulf Cooperation Council -based institutions that have successfully introduced Islamic insurance products (Ongena, 2013).

\subsubsection{In the United States}

The Islamic banking and financing activities and actions has been included in financing transactions at consumer level. The first attempt to bring Islamic banking and financing to the United States was made in 1990 when the Office of the Comptroller of the Currency recognized formally Murabahah and Ijarah models to be 
valid for transactions. By 1999 the Dow Jones Islamic Market Index have been lunched and created for investors who seek equity Shariah-compliant investments. Islamic banking and finance has differently grown in the states than in other areas in the world. The US Islamic banking and finance industry remains a niche segment in the Northern American financial sector (Farooq \& Zaheer, 2013). 


\section{Chapter 4}

\section{MONETARY POLICY IN ISLAM}

\subsection{Definition of Monetary Policy}

Monetary policy has existed under many shapes. However it may appear, generally to adjust the money supply in the economy to accomplish some set of output and stabilization inflation. Most economists would supplement that in the long-run outputs are constant, then any money supply changes only affect prices to change. Usually wages and prices cannot immediately adjust in the short-run, changes in supply of money will affect the actual production of services and goods. These reasons let central banks to conduct monetary policy, for example, the European Central Bank and the U.S. Federal Reserve is a useful policy tool for accomplish both growth objectives and inflation (Mathai, 2009).

For example, in a recession, consumers spend less than they used to spend; business production decreases, leading firms to stop investing in any new investment. In brief, there is a decreases in aggregate demand to which government can respond with a policy that leans against the direction in which the economy is headed. Usually monetary policy is that countercyclical tool of choice. This countercyclical policy will lead to the desired expansion of outputs. But, because it requires a rise in supply of money, it will also affect prices to increase. As in production at full capacity economy get closer, increase on demand will put stress on costs of inputs, involving wages. Then workers use the increasing in their income to purchase more goods and services, 
usually more bidding up wages and prices and pushing generalized inflation outcome policymakers want to avoid (Peter, 2008).

\subsection{Objectives of Monetary Policy}

The primary objective of monetary policy is the stability in long-run prices. In fact, the inflation expectation in crisis became so important, which may have played main role for avoiding deflation fluctuations during the crisis. The crisis did challenge the notion that price stability is sufficient for macro (output) stability and raised the question of whether other objectives should enter the mandate of monetary policy and, more generally, central banks. Monetary policy will have a huge impact in helping to protect financial stability. Two different methods could be used. One method is to do so in a flexible inflation-targeting regime with a lengthened horizon. In that field, central banks would react to financial imbalances to the extent that they represented a threat to long-term price stability. So, for example, when the product or the business activity increases rapidly, the policy rate will be directly proportional to the business activity. The price will not be kept as promised, concerning that emerging financial imbalances could lead to a huge decrease in the activities of the product or the business. A substitute method would be to establish financial stability as a supplementary target independent from price stability but also attached with it to a certain point. Although the central bank will consider the indication of the financial stability for output stability, and to such degree, inflation pressures. Under those conditions, it would be highly predictable to react to imbalances even if they do not cause any danger to price stability (Bayoumi, 2014).

Lastly, the sequences of this strategy actions on the observance of the financial markets may be hard to forecast and abduct in the extremely deep quantitative models that, until now, have implemented conveyance for monetary policy. If so, 
"approaches" from much more complex qualitative models will have to be taken into consideration (Ricardo, 2010). Until these concerns are better comprehended, monetary policy will include less science and more art than before the crises.

\subsection{Monetary Policy in Islamic Banking}

Much of the studies on Islamic banking greatly concentrated on the development and the establishment of the financial tools that are considered as acceptable, generally monetary policy consist of financial tools descriptions that the domination could hire employees to change the rates of return and the quantity on financial requirements in the economy. There are various policy tools handling domestic liquidity, in spite of prohibiting discount rates and other open market activities dealing with interestbearing securities. Islamic economy has been labeled newly in a variety of studies and articles. These consist of, for instance, selective and overall controls on credit flows, changes in reserve requirements, changes in monetary base via currency management affairs, and moral suasion (Ziauddin, 1983).

The monetary powers have the potential of immediately changing the rate of return either on loans or deposits by changing the expected ratios of the public and the banks, they are also expected to share losses and profits that are related to bank operations, for example, the profit and loss sharing ratios. However, it is critically causing a conflict relating to the change of the determined ratio that the bank is operating. On the other hand, some critics argued that the profit and loss sharing ratio that the bank is operating is a major goal in accomplishing the monetary stability, also mentioning that those operations that the bank takes, only affects new deposits and has no impact on the existing ones. Open market activities and actions could still conduct with non-fixed interest securities (Ziauddin, 1984). 


\subsection{Monetary Policy Tools in Islamic Economy}

The monetary policy is considered as one of the main tools of macro-economic policy with multiple objectives, in accordance with the used tools. In general it is not possible to await achieving two independent objectives through one means or tool. This approach is justified by the lack of reasonableness of allocation of one means to achieve the goals of the multi-non-homogeneous nature, and opposed in treatment. Therefore, monetary policy is assigned the goal of price stability through monetary discipline.

Because of the strong structure of Islamic economy and its elements, that reserve its safety, particularly with respect to the banking side, the occurrence of monetary imbalances is often excluded in this process because of the version as pursuant to sovereign right of the State, in addition to preventing banks money derived from written, which are the most important causes of inflationary pressures, the prohibition of usury, and the absence of the gap between savings and investment decisions. As in the case of some monetary imbalances, it can be in this context the adoption of a set of tools and methods: 


\section{Quantitative Tools in Islamic Monetary Policy}

They're called that because they aim at influencing the volume of money in circulation, namely:

a. Changing allocation ratios of the current deposits: so accordingly to prohibition of hoarding in Islam, the zakat funds as a punishment for stalled, and savers' desire to get profits instead of depositing at no charge. The ratios of current deposits in the banks are very low compared with the investment deposits. However, the compilation of many quantities of it constitutes large chunky amounts, so central bank interferes to change the allocation of these deposits by distributing them to appropriate institutions and using them in the required areas, according to the desired monetary policy.

b. A change in the Zakat monetary ratio: Where the monetary authorities to decide Zakat collection in cash, and distribution in kind, or distribution in cash and collection in kind, or to combine the two methods in varying ratios. Also, the State can change the date of the Zakat collection, and this is either voluntarily or at the request of the general interest, depending on economic conditions. The Zakat can be distributed between consumer or capital goods, according to a need for economic activity in the State, and thereby achieving a balanced growth and preventing monetary and commodity imbalances in the society (Kahf, 2002).

c. Open-market policy: This means the Central Bank's selling and purchasing of stock and government bonds in the open market, whether from banks or individuals. In order to influence the level of monetary standard. In view of the outlaw Riba in Islamic regime, it's permissible to deal by name because they are part of the capital of companies and it's borne by the profits and losses, and are guided by real variables, not abstract ones because they reflect the real activity, and are not subject 
to rigid price expectations of speculators as in conventional system. It can be dealt with bonds issued by the State and aims to involve the public in the various development and productivity projects, or to finance emergency expenditures that exceed the energy employment, or to absorb surplus cash in the market (Mohsin \& Abbas, 2010).

d. A change in the proportion of distributed profits and share the rate of profits and losses: The tool includes central bank intervention in determining the percentage of distributed profits to shareholders. If the monetary authorities would like to increase the size of the money supply, they raise the proportion of profits distributed for savers and depositors of their money in banks for investment, in order to encourage them to do more investment deposits and to attract new investors, and vice versa. In the case of their desire to reduce the size of the money supply. Moreover, intervention to change the rate of participation between the Bank and depositors, on one hand, and the ratio of participation between the Bank and investors, on the other hand (Jamal, 2007).

\section{Qualitative tools in Islamic monetary policy}

These tools are used to directing the financial resources to vital sectors needed by the community more than other sectors. According to the order of the needs of the State and individuals. These tools may be a distinction in the proportions of the abovementioned quantitative tools or other complementary tools.

\section{a. Discrimination in current deposits to investment areas}

The allocation ratios of current deposits in the banks can be modified, according to economic activity need and priorities. If the quantitative tool in this area changes allocation ratios of current deposits, according to the state of economic activity in general. It is use as a tool to how to deal with the part that was allocated for 
investment, as it is specialized to the priority sectors or sectors suffering a contraction in financial resources. Therefore, small investor's loans, banks' investment, and even the good government loans allocated to these sectors.

\section{b. Discrimination in the proportion of Zakat Monetary}

Where discrimination and selectivity in the proportion of Zakat monetary, both in terms of collection in cash and in kind, or in presentment or delaying the collection date, in accordance to sectors that The Central Bank wishes to narrow or expand the resources available to them (Kahf, 2002).

\section{c. Discrimination in dealing in the open market}

In order to influence the economic sectors without others, the Central Bank purchased securities of the desired strengthening sectors to increase the financial resources allocated to these worships, and investors' interest in them, in limits of quantity, which the Central Bank wants to add to the economy of the money supply. In return, The Central Bank does not buy securities of sectors that it doesn't not wish to increase their funding, or even sell part of securities it has of these sectors (Mohsin \& Mirakhor, 1985).

\section{d. Discrimination in the rates of participation in profits and undistributed profits:}

The discrimination in the rates of participation in profits and undistributed profits makes investments head to areas need to be developed. If the monetary authorities want to direct financial resources toward certain sectors, it will raise the rate of participation in favor of depositors at the expense of the banks to increase their deposits. It also raises the percentage of participation in favor of investors at the expense of banks to increase their investment in these sectors, and raises the 
proportion of distributed profits in these areas, and vice versa for the sectors, known as inflation, or is not a priority for the interests of the State and individuals.

\section{Supplementary tools}

They are tools that complement the role of the tools, mentioned above, in directing monetary resources toward desired sectors, including:

\section{a. The proportion of the banks in investment activity}

It is the amount contributed by the banks of loans to finance activities of small investors, other investments and loans, to be paid to the owners of these projects, and the remaining part of their own resources and this percentage can be determined and adjusted by the monetary authorities depending on the priority of economic activities and their financial state.

\section{b. Terms of Murabaha}

It is the sale of a commodity at cost price with the addition of known price, agreed between sectors used and suppliers or exporters. It contributes to the various areas of economic activity, as it provides the needs of the internal and external trade sectors through activating buying and selling in the domestic market. As well as it contributes to raise the size of the aggregate demand and economic activity. This tool serves to "ensure that concentration and diversify of the facilities in different investments vary in the degree of risk, to protect the funds of the Bank and safety of customer deposits (Autumn, 1995). 


\section{Direct tools of Islamic monetary policy}

It is the actions through which the Central Bank directly interfere with the provisions of the application of monetary policy, particularly in critical economic situations, which require large and rapid changes in the size of the money supply, and these actions are (Salhi, 2001).

\section{a. Faith Persuasion}

It is the central bank intervention to persuade banks with the procedures to be followed to address the problems of the economy. This is the belief in the need of the provision of public need at the expense of the individual need. It is usually done through a direct meetings with the managers of banks.

\section{b. Direct instructions}

The Central Bank uses it when the means of faith doesn't succeed, where it draws binding instructions to banks to apply the necessary procedures to implement monetary policy (Jamal, 2007).

\section{c. Direct control}

As for the purpose of the provisions of the process of the Central Bank's supervision of banks and ensure of consistency within the banking system in the interest of the economy as a whole, it handles the direct control procedures to various banks to assess the extent of its commitment to the actions specified by it and decides what is appropriate for or against these banks.

\section{d. Sanctions}

They are the last resort of the Central Bank of the procedures to ensure the implementation of its instructions to banks, and these sanctions could be negative such as deprivation of lending and financing, or imposing fines as irregularities committed by, and up to stopping the activity of these banks. These sanctions may 
also be positive as the encouragement of banks abiding central bank's directives by providing incentives to reward them, which stimulate other banks to abide by the instruction of the central bank on monetary policy.

\section{e. Media}

The declaration of central bank's future monetary policy in cash resources in terms of quantity and quality, backed by figures and statistics. Therefore, it puts the facts before the public opinion, which increases awareness of internal economic, pushing commercial banks to cooperate in order to implement this declared policy, and this increases the public confidence in those procedures and economic policy established by the monetary authority (Salhi, 2001).

\subsection{The Effectiveness of Monetary Policy Tools in Islamic Economy and the Extent of its Use as an Alternative for Conventional \\ Economy Tools:}

The importance of monetary policy in achieving the objectives of the economic policy of the State is linked to the extent of their effectiveness. It doesn't make a sense for a policy not to be able to achieve these goals. Therefore, it is necessary to evaluate the effectiveness of the most important Islamic monetary policy tools and the appropriate cases for their success, so it can be used as an alternative to the tools used in conventional economic system. 


\subsection{The Assessment of the Effectiveness of the use of Monetary Policy Tools in the Islamic System}

Through what has been reviewed in advance of monetary policy tools in Islamic economy, it can be said that this system has protected by self-stability factors that protect it from monetary imbalances, through its tools which the effectiveness of its use can be assist as follows:

- The authorities of the guardian achieve the interests of the nation, and in the area of monetary policy, the monetary version is considered as a sovereign right of the State, and any other side is prevented from this right, and this gives the authority the full capacity to control the supply of money.

- Strong economic and social effects of Zakat, through the intervention of the redistribution of income and wealth in favor of the poor, which increases the volume of consumption and investment, particularly in the context of the actual requirements of essential goods, and their application to the stalled resources which are considered as a tax required to be paid by investment funds and preventing hoarding.

- The prohibition of Riba, which is the most important cause of economic fluctuations, through the creation of credit of large quantities that are not absorbed by the economies of the countries, whatever the degree of its production flexibility is. Also the non-payment of usury installments reduces the costs of production, which leads to lower prices and increased consumption and production increase, and these are all of the most important goals of monetary policy.

- The adoption of the system of participation and what it achieves of justice in the distribution of profit and risks between financiers and investors, and 
thereby the achievement of stability in economic activity and reduction of the fluctuations caused by expectations of businessmen on the future of the investment process.

- The system of participation makes financiers and investors together doing all their efforts to the success of their projects through good study, and follow-up to the minute, which is more effective in the area of investment. The Islamic companies, funds companies in particular, are the best alternative for asthmatic financing.

\subsection{Monetary Policy Tools in Islamic Economy Alternative to}

\section{Conventional Economy Tools}

The Zakat as one of monetary policy tools in the Islamic economy alone is considered as an integrated economic and social system. If we add to the rest of the other tools to it, like the central bank control in the distribution of current deposits in the commercial banks, then control in the distribution of profits and losses and open market operations as a quantitative tools, in addition to other qualitative tools that are direct in Islamic economy, we find that these tools are the best alternative to those used in the conventional economy as interest rate and legal partial reserve.

Table 2: Alternatives to monetary policy tools in positive economy from Islamic economy

\begin{tabular}{|c|l|l|l|}
\hline No & The tool in the Islamic economy & Instead of & $\begin{array}{l}\text { The tool in the conventional } \\
\text { economy. }\end{array}$ \\
\hline 1. & $\begin{array}{l}\text { Change allocation ratios of current } \\
\text { deposits. }\end{array}$ & $\longrightarrow$ & Change in the ratio of legal reserve. \\
\hline 2. & $\begin{array}{l}\text { Change in the ratio of Zakat } \\
\text { money. }\end{array}$ & $\longrightarrow$ & $\begin{array}{l}\text { Financial Policy and increasing } \\
\text { taxes. }\end{array}$ \\
\hline 3. & Open-market policy. & $\longrightarrow$ & Usury open-market policy. \\
\hline 4. & $\begin{array}{l}\text { Change in the ratio of distributed } \\
\text { profits and participation rate of } \\
\text { profits and losses. }\end{array}$ & $\longrightarrow$ & The discount rate policy. \\
\hline 5. & Discrimination in current deposits & $\longrightarrow$ & Discrimination in the ratio of legal \\
\hline
\end{tabular}




\begin{tabular}{|l|l|l|l|}
\hline & addressed areas. & & reserve. \\
\hline 6. & $\begin{array}{l}\text { Discrimination in dealing in the } \\
\text { open market }\end{array}$ & $\longrightarrow$ & Deal on the open market. \\
\hline 7. & $\begin{array}{l}\text { Discrimination in the percentages } \\
\text { of participation in profits and } \\
\text { undistributed profits. }\end{array}$ & $\longrightarrow$ & Discrimination in discount rate. \\
\hline 8. & $\begin{array}{l}\text { The proportion of the banks in } \\
\text { investment activity. }\end{array}$ & $\longrightarrow$ & Required security margin Policy. \\
\hline 9. & Terms of sale Murabaha. & $\longrightarrow$ & REAL ESTATE CREDIT. \\
\hline 10 & Faith Persuasion. & $\longrightarrow$ & Moral persuasion. \\
\hline
\end{tabular}

Table (2) including but is not limited to the tools in Islamic economy is clearly introduced and explained in the below points:

1. Tool of ratios change of allocation of current deposits is considered the best alternative for tool of ratio change of the conventional legal reserve in the conventional system. As the latter is the main reason for the monetary imbalances that occur in the economies of the developed countries in the current period. While ratios change of allocation of current deposits policy prevents additional money creation illegally, and, in return, it gives the right to take advantage of the real current deposits in the banks, allowing the Central Bank through change of the ratios of these stocks, to achieve the objectives of monetary policy.

2. Tool of ratios change of Zakat monetary can be considered strong alternative for the financial effects of monetary policy. Despite the great difference between them, as the latter is considered the second tool causing momentary imbalances after commercial banks that create recent instrument. 
3. The open market policy, as stated above, appears to be largely identical to that used in the conventional economy, but in fact it differs substantially. As this policy in conventional systems" is a like gambling, for its adoption rates mainly in trade, as the motive for the exchange of these papers, as well as the corresponding paying paid is usually imaginary money created by commercial banks in the stock exchange, which generate a wave of fluctuations in prices and create paradoxical situations of optimism and pessimism, and is with a negative impact on the real economy (Allais, 1993). However, in the Islamic system, these operations are not recognized, but it's dealt with real and not nominal balances, permitting only bonds or investment certificates for profit and loss, and they represent shares in economic institutions, in accordance with specific rates of loss and profit.

4. Tool of rate change in the proportion of distributed profits participation rate of profits and losses is considered as alternative for discount rate policy in the conventional system that is rejected in the Islamic system because the performance of its role depends on the interest rate, which the scholars considered it identical to Riba, which is religiously prohibited.

5. Tool of discrimination in current deposits directed to investment areas is an alternative for policy of discrimination in the proportion of legal reserve that is rejected in Islamic system to because it enables commercial banks of credit creation and their interaction with what they do not have.

6. The policy of discrimination in dealing in the open market is considered as an essential alternative for similar policy in the conventional system, through its handling of forbidden assets, and legitimate means. 
7. The policy of change of the rate of the distributed profits and participation rate of profits and losses is an alternative policy of the rediscount rate, therefore, this tool can be counted as an alternative for policy of discrimination in the rediscount rate, that is rejected in the Islamic economic system, for it depends on usury interest.

8. The complementary tool for Islamic banking presented in the rate of bank contribution in investment activity is a substitute for the policy of required security margin in the conventional system, and it does not differ from it except that the latter the deals with forbidden usury interests because Islamic banks are based on the method of participation its contribution to finance the various investment projects.

9. The tool of the terms of Murabaha is a similar policy to the tool of change the terms of sale in installments, which is considered as a kind of Murabaha, provided that the increases not interest, but a halal profit. It is considered as a substitute for real estate credit, provide that the first installment, and installments are calculated on legitimate not usurious basis.

10. The Islamic banking activity is more of a message than a trade. It deals with commercial banks basing on a religious faith, through the use of a tool of faith persuasion in terms of provision of the public interest on account of special interest. This tool is an alternative for policy of moral persuasion in the conventional economy, which the prospective success of its use depends on the prestige and position of the Central Bank and the personality of the officials responsible for the administration. 
It may come to mind that the application of these tools of Islamic economy as an alternative to the conventional economy in people's reality means cancellation of existing economic institutions and all banks and companies that are not based on the Islamic bases and principles in the economy and finance, but the real thing isn't this superficial (Kana, 2009). 


\section{Chapter 5}

\section{CONCLUSION}

For years, Islamic banking industry has witnessed a dramatic growth. Other potential markets across the world are still untapped especially those with a high Muslim populations, for example India. At the same time, new markets around the world opened up for the Islamic Banking and Finance Industry. Interestingly, Islamic banking outpaced conventional banking in most countries. It is important also to mention that Islamic banks out-performed Conventional Banks in terms of growth because Islamic bank got the trust of people. Many things have challenged the decreasing profitability and slowing growth of Islamic Banking. For instance, Conventional banks are bigger than Islamic banks in their local markets. Even more, International Conventional banks are big compared to Islamic banks. In relation to the competition between both Conventional and Islamic Banks, number of Islamic banks are growing with the time. To ensure faster growth, Islamic banks have to engage more qualified and experienced staff than Conventional banks. On other hand, Islamic Banks have to shed the light on specific investment opportunities in different sector that could give long term returns. When Islamic Banking idea appeared, Conventional Institutions declared it not possible. Successful operations of Islamic Banks in the non-Muslim counties has been always a real concern. There was several opinions in relation to this concern including. For example, Islamic bank will not operate successfully in the non-Muslim countries. Other opinion declared that the ethic sense and finance that is directly linked to Islamic Banks could apply to non-Muslim 
countries because as mentioned before that many Islamic banks worked now in nonMuslim countries. For instance, UK, France, Italy, Untied state and Germany. During the last two decades, Islamic Banking and finance industry is growing rapidly and has showed significant expansion and dramatic growth. By the end of 2013 the global volume of the in-compliance with Shariah, assets has exceeded US \$ 1,700 Billion, displaying a growth of $21 \%$ from 2007-13 (GIBCR-2014). MENA region is considered as the center of Islamic banking and finance market and contributes $74 \%$ share in global assets under Islamic finance, followed by East Asian region with a share of $17 \%$ while $9 \%$ from rest of the world (IFSL, 2013). Share of banking assets is $90 \%$ followed by equity funds $5 \%$ and the rest are others in the global volume of assets under Islamic finance. In Pakistan, Islamic financial services are expanding nationwide and by the end of September 2013 the number of Islamic Banking Institutions (IBIs) has reached to 19 with a branch network of 1,161 . Islamic finance has grown at $28 \%$ per annum for 2008-13that showing how numbers of Islamic banks increasing and rising in the world (SBP-2013).

On other hand, we find that, despite the similarity of the monetary policy objectives in the two systems, Islamic and conventional, namely. But the differences appeared in the tools used in both system. The adoption of the tool of participation system and what it achieves of justice in the distribution of profit and risks between financiers and investors and other tools mentioned before, made the Islamic system lives selfstability away from emergency economic fluctuations, and if there were external or emergency reasons, they can be faced with these powerful tools of monetary policy, which are the best alternative for those tools used in the conventional economy, as the latter and because of what it has of dangers on the monetary system still overthrows 
various monetary systems of various countries of the world, especially in the current period of global financial crisis spreading at the level of all the globe.

In the latter, in the light of the foregoing, suggestions, that could be a modest contribution through which we can formulate economic policy that achieves objectives of Islamic policy, through Islamic tools in monetary policy instead of the conventional. First, the need to prevent dealing with conventional banks, and thus returning to the inclusion of the ethics of Islamic economy through its tools in the monetary policy and, in particular, the participation to achieve the benefits of that sooner or later. Second, Giving Zakat Fund special importance to take advantage of the useful economic and social effects of the Zakat system. Third, central banks must open special treatment with Islamic banks, especially in an environment full of conventional banks. Forth, The adoption of a monetary policy with legitimate tools based on the Prohibition of Riba, instead of conventional monetary policy. Finally, the best that we recommend is the need to assume decision-makers and officials to bear the issue of Islamic economy and therefore the application of its principles, because the problem is not in the economic system of Islam, as it is an integrated divine system, but the problem is in those applying this system. Therefore, we recommend that every one of us claims his responsibility for the introduction of fundamentals of our Islamic economy so that it could be applied by the best. 


\section{REFERENCES}

[1] Ahmad, A. (1987). Contemporary Practices of Islamic Financing Techniques: Islamic Research and Training Institute. Development and Problems of Islamic Banks. 23-24.

[2] Al-Zuhayli, W. (2008). AI-Mausu'at al-Fiqhiyyah. 9, 96-110. (Arabic)

[3] Al-Debo, I. (2008). Islamic economy. Dar Al-Manahej Publications, AmmanJordan. 73-75. (Arabic).

[4] Allais, M. (1993). Monetary conditions for economic market. Islamic Institute for Research and Training. 53-55.

[5] Al-Zuhayli, W. (1984). Al-Fiqh al-Islami WA Adillatuh, 3rd ed. Damascus: Daral-Fikr. 4, 466-467.

[6] Ameer, H. \& Ansari, S. (2014) Islamic Banking: Ijarah and Conventional Leasing. Thesis of Islamia University of Bahawalpur, Department of Management Sciences.

[7] Anthony, M. (2000). What Monetary Policy Can and Cannot Do? Federal Reserve Bank of Philadelphia, Business Review. 1-4.

[8] Anton, K. (2010). Regulating Capital Flows to Emerging Markets: An Externality View. Working paper. University of Maryland mimeo.

[9] Arham, M. (2010). Islamic perspectives on marketing. Journal of Islamic Marketing. 1, 2-5.

[10] Awan, A. G. (2009). Comparison of Islamic and Conventional Banking of Pakistan. Working paper. Department of Economics, Islamia University, BahawalpurPakistan. 
[11] Bayoumi, T. \& others (2014). Monetary Policy in the New Normal: Monetary and Capital Markets, and Strategy and Policy Review Departments, Brazil. Research. 7-9.

[12] Benes, J., A. Berg, R. Portillo, \& D. Vavra (2013). Modeling Sterilized Interventions and Balance-Sheet Effects of Monetary Policy in a new-Keynesian Framework. Washington: International Monetary Fund.

[13] bnda'as, J. (2007). Monetary policy in Islamic and conventional. Dar El Khaldon, Algeria. 225-232. (Arabic)

[14] Cevik, S. \& Charap, J. (2001). The Behavior of Conventional and Islamic Bank Deposit Returns in Malaysia and Turkey. Working Paper. Middle East and Central Asia Department. 4-14.

[15] Cornell, V. J. (2002). A Muslim to Muslims: Reflections after September 11. Journal of the South Atlantic Quarterly.101-105.

[16] Farooq, M. \& Zaheer, S. (2013). Are Islamic Banks More Resilient during Financial Panics? Working Paper. Research Department and Strategy, Policy, and Review Department.

[17] Farooq, M. O. (2006). The Doctrine of Ijma: Is there a consensus? Working paper. Upper Iowa University.

[18] Gürkaynak, R. \& Levin, A. \& Swanson, E. (2010). Does Inflation Targeting Anchor Long-Run Inflation Expectations? Evidence from the U.S., UK, and Sweden. Journal of the European Economic Association. 8(6), 1208-1242.

[19] Hamed, I. (2013). Islamic banking in Germany: opportunities and potential aspects. Thesis. University of Applied Science Worms.

[20] Hanif, M. (2011). Differences and Similarities in Islamic and Conventional Banking. International Journal of Business and Social Science. 2, 170-181. 
[21] Ireland, Peter N. (2008). Monetary Transmission Mechanism. In the New Palgrave Dictionary of Economics. 3ed. by Steven N. Durlauf and Lawrence E. Blume (Hound mills, Basingstoke, United Kingdom: Palgrave MacMillan, 2nd Ed.).

[22] Kahf, M. (2002). Economics of Zakah. 2ed. Islamic Development Bank Jeddah. 393-394.

[23] Kamali, M. (2003). Principles of Islamic Jurisprudence. 3ed. UK: Islamic Texts Society, Cambridge. 220-51.

[24] Kana, A. (2009). Monetary and currency exchange economies. Dar AlKhaldunia Publications, Algeria. 55-63. (Arabic).

[25] Khan, M. \& Mirakhor, A. (2010).The Financial System and Monetary Policy in an Islamic Economy: Assistant Director and Economist Research Department. International Monetary Fund, Washington.

[26] Labonte, M. (2014). Monetary Policy and the Federal Reserve: Current Policy and Conditions Specialist in Macroeconomic Policy. Congressional Research Service. 6-9.

[27] Matha, K. (2009). What Is Monetary Policy? Finance \& Development, United Kingdom.

[28] Mauro, F., Caristi, P., Couderc, S., Maria, A. D., Grewal, B. K., Masciantonio, S., Ongena, S. \& Zaher, S. (2013). Islamic finance in Europe. Occasional Paper SERIES no. 146. 25-32.

[29] Mawdudi, S. (2010). Economic System of Islam. Islamic publications Ltd. 37-39.

[30] Mishkin, Frederic S. (2000). What Should Central Banks Do? Review, Federal Reserve Bank of St. Louis. 1-14. 
[31] Nabhani, T. (1997). The Economic System of Islam. 4ed. Al-Khilafah Publications. 11-33.

[32] Qur'an. Surat Al-Baqarah from Ayah. 275.

[33] Qur'an. Surat Al-Baqarah from Ayah. 278.

[34] Qur'an. Surat Al-Baqarah from Ayah. 279.

[35] Rasche, R. \& Williams, M. (2007). The Effectiveness of Monetary Policy. Federal Reserve Bank of St. Louis Review. 89, 447-89.

[36] Ricardo, C. (2010). Macroeconomics after the Crisis: Time to Deal with the Pretense-of-Knowledge Syndrome. Journal of Economic Perspectives. 4, 85-102.

[37] Salhi, S. (2001). Monetary policy in sharing system. Dar El-Wfa'a Publication, Egypt.104. (Arabic)

[38] Shams, M. (2011). Comparison between Ijara and Conventional Leasing. Working paper. NUST business school.

[39] Usmani, M. (2002). An Introduction of Islamic finance. The Hague: Kluwer Law International. 17-29.

[40] Wilson, R. (2000). Challenges and Opportunities for Islamic Banking and Finance in the West: the United Kingdom Experience. Thunderbird International Business Review. 41, 36-40.

[41] Ziauddin, A. (1983). Money and Banking in Islam: Institute of Policy Studies. Journal Research of Islamic Economy.3, 94-99.

[42] Ziauddin, A. (1984). Concept and Models of Islamic Banking: An Assessment. Paper presented at the Seminar on Islamization of Banking, Karachi. 